\title{
Electrochemical Behaviour of 5-Methyl-4-(2-Thiazolylazo)-Resorcinol in Micellar Media
}

\author{
Ahmet KARAÇELIK $^{1}$ (D) Yeliz KARAMAN ${ }^{2}$ (D) Saim TOPÇU $^{1 *}$ (D) \\ ${ }^{1}$ Giresun University, Sciences and Arts Faculty, Department of Chemistry, Giresun, Turkey. \\ ${ }^{2}$ Sinop University, Sciences and Arts Faculty, Department of Chemistry, 57000 Sinop, Turkey
}

Geliş / Received: 24/05/2021, Kabul / Accepted: 26/06/2021

\begin{abstract}
In this study, surfactant effects on the spectroscopic and electrochemical behavior of 5-Methyl-4-(2thiazolylazo)-resorcinol were studied in an aqueous solution at neutral $\mathrm{pH}$. Dodecylpyridinium chloride (DDPC), cetylpyridinium chloride (CPC) (cationic), Triton X100, Tween 20 (nonionic), and sodium dodecyl sulfate (SDS) (anionic), were used in investigation. A large bathochromic shift of absorption maxima of the dye was observed upon the addition of surfactant. Electrochemical reduction of the dye was investigated by cyclic voltammetry $(\mathrm{CV})$. The adsorption-controlled reduction reaction of the dye changed to a semireversible diffusion-controlled reduction peak at $-0.43 \mathrm{~V}$ by the addition of CPC. Depending on the CPC concentration in the dye solution, the peak potential of the electrode reaction shifted about $120 \mathrm{mV}$ in the cathodic direction and the peak current decreased up to ten times. These changes were interpreted depending on the type and concentration of surfactant present in the solution.
\end{abstract}

Keywords: Surfactant, critical micelle concentration, electrochemical, spectroscopic, 4-(2thiazolylazo)orcinol (TAO).

5-Methyl-4-(2-Thiazolylazo)-Resorcinol'ün Miselli Ortamdaki Elektrokimyasal Davranışı

$\ddot{O} \mathbf{z}$

Bu çalışmada, 5-Metil-4-(2-tiazolilazo)-resorsinolün spektroskopik ve elektrokimyasal davranışı üzerindeki yüzey aktif madde etkileri, nötr pH'ta sulu bir çözeltide incelenmiştir. Araştırmada dodesilpiridinyum klorür (DDPC), setilpiridinyum klorür (CPC) (katyonik), Triton X100, Tween 20 (noniyonik) ve sodyum dodesil sülfat (SDS) (anyonik) kullanılmıştır. Yüzey aktif maddenin eklenmesi üzerine boyarmaddenin absorpsiyon maksimumunda büyük bir kırmızıya kayma gözlendi. Boyanın elektrokimyasal indirgenmesi döngüsel voltametri $(\mathrm{CV})$ ile araştırıldı. Boyarmaddenin adsorpsiyon kontrollü indirgeme reaksiyonu, CPC ilavesiyle 0,43 V'de yar1-tersinir difüzyon kontrollü bir indirgeme pikine dönüştü. Boyarmadde çözeltisindeki CPC konsantrasyonuna bağlı olarak elektrot reaksiyonunun pik potansiyeli katodik yönde yaklaşık $120 \mathrm{mV}$ kaydı ve pik akımı on kata kadar düştü. $\mathrm{Bu}$ değişiklikler, çözeltideki yüzey aktif maddenin tipine ve konsantrasyonuna bağlı olarak yorumlandı.

Anahtar Kelimeler: Yüzey aktif madde, kritik misel konsantrasyonu, elektrokimyasal, spektroskopik, 4-(2Tiazolazo)orsinol (TAO).

\section{Introduction}

Electrochemical studies of aromatic azo compounds have been the subject of many investigations because of (i) the importance of this group in the dyestuff industry (ii) interest in carcinogenic properties and (iii) the use of azo compounds for indirect determination of metal ions (Karaman et al 2015, Uçarlı 2020). Also, thiazolylazo derivatives have been used in chromatographic and spectroscopic studies (Wang 1999, Smolinska et al 2015). 
Recently, attention has been devoted to micelles in developing analytical methods such as micellar liquid chromatography, surfactant sensitized spectroscopic determinations (Das et al, 1997, Amin A, 2000). Application areas of surfactants are not limited to analytical purposes, and they were added as catalysts for many reaction media. We previously investigated the catalytic decomposition mechanism of 5-Methyl-4-(2-thiazolylazo)-resorcinol (5-Me-TAR) in surfactant solutions (Menek et al, 2006).

Determination of electroactive substances in the micellar medium has advantages over conventional methods in the view of selectivity, sensitivity, low toxicity and applicability (Sener et al 2020, Allahverdiyeva et al 2020). Also, micelles might significantly change the redox potential of electrode processes, as well as change diffusion coefficients, the stability of electrochemical intermediates or products (Topçu et al 2003, Wu et al 2016, Rajeev et al 2017).

Thiazolylazo compounds have been used successfully as chelating agents in adsorptive stripping voltammetric determination of trace metal ions (Gazarov et al 2016, Toncheva et al 2018, Genc et al 2020). Analog dyes 1-(2-Thiazolylazo)-2-naphthol (TAN), 4-(2Thiazolylazo)-resorcinol (TAR) and 2-(2-Thiazolylazo)-p-cresol (TAC) have been investigated in different media (Croot et al 2000, Fraga et al 2000, Hamza et al 2021). Many researchers investigated the reduction mechanism and the number of electrons transferred in the reduction of azo dyes in aqueous and non-aqueous media (Karaman 2012, 2014).

Despite the importance of surfactant effects on electrochemical and spectroscopic properties of dyes, there is limited information available in the literature (Gomes et al 1999, Rahman et al 2013, Dash et al 2021). Our study discusses the effects of various surfactants on both the spectroscopic and electrochemical behavior of azo dye. Cationic, nonionic, and anionic surfactants, such as DDPC, CPC, Triton X100, Tween 20, and SDS, were used for comparison. The spectroscopic and electrochemical behavior of the dye is largely dependent on the surfactant concentration. The increase in surfactant concentration caused shifts in the peak potential and a decrease in the peak current of the dye. In the evaluation of absorption studies with voltammetric results, it was determined that Coulomb interactions play a primary role in the nature of dye-surfactant interactions. In particular, cationic surfactants have a more dominant effect on the electronic spectrum and electro-reduction.

\section{Material and Methods}

Absorption spectra were recorded with UNICAM UV/VIS Spectrometer UV2 from $300 \mathrm{~nm}$ to $600 \mathrm{~nm}$ at a concentration range $\mathrm{C}_{\text {surfactant }}>>\mathrm{C}_{\text {dye }}$ by using $1 \mathrm{~cm}$ quartz cuvette.

Voltammetric experiments were conducted using a computer-controlled electroanalysis system (Metrohm 757 VA Computrace Electrochemical Analyser). A three-electrode combination system was used. This consisted of a Multi-Mode electrode (HMDE), a Ag/AgCl reference electrode, and a Pt wire auxiliary electrode. All measurements were conducted at 20 $\pm 1^{\circ} \mathrm{C}$. The ionic strength of the solutions was adjusted to 0.1 with $1 \mathrm{M} \mathrm{KNO}$. The solutions were purged with purified nitrogen for five minutes before the experiments to remove dissolved oxygen from the solution. After the nitrogen gas passage, it was waited for about 15 min for the foaming on the solution to be removed and the solution to become stagnant. Cyclic voltammetric experiments in micellar solutions were conducted at scan rates in the range of $20-2000 \mathrm{mV} / \mathrm{s}$. Solutions at different surfactant concentrations were made in the electrochemical cell by adding appropriate volumes of stock surfactant solutions to the dye solution in $\mathrm{KNO}_{3}$ using a microsyringe.

The dye solution, 5-Me-TAR (Aldrich), was prepared fresh prior to each determination (Fig. 1). $1 \times 10^{-3} \mathrm{M}$ stock solution was prepared by dissolving the compound at least amount of absolute ethanol. Surfactants (CPC, DDPC, Triton X100, Tween 20, SDS) used as purchased 
and $0.1 \mathrm{M}$ stock solutions were prepared in water. All the chemicals employed were of analytical grade and all solutions were prepared using ultrapure water (18.4 M $\Omega$ ).

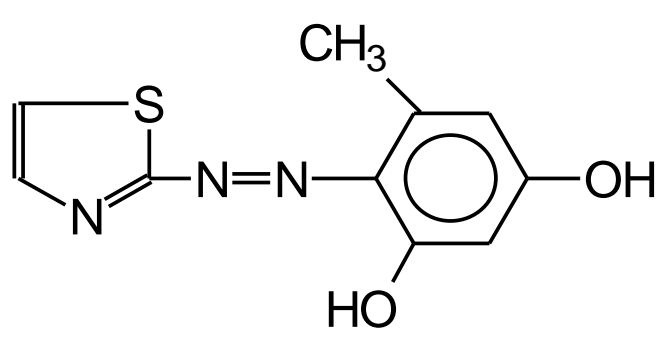

Fig. 1 The molecular structure of 5-Methyl-4-(2-Thiazolylazo)-Resorcinol.

\section{Results and Discussion}

\subsection{Surfactant Effects on Visible Spectrum of Dye}

The visible spectra of the dye were investigated by mixing a fixed concentration of dye with various concentrations of the surfactant. The concentration range is arranged to include both below and above critical micelle concentration (CMC). The addition of surfactants caused large bathochromic shifts on $\lambda_{\max }$ of the dye.

As a representative, the change in the absorption spectra of 5-Me-TAR with varied concentrations of DDPC is shown in Fig.2. Without surfactant, an absorption maximum $\left(\pi-\pi^{*}\right)$ was observed at $421 \mathrm{~nm}$ originating from the conjugated system of the dye. The first stage of surfactant addition caused a rise in the absorption peak, which indicates the solubilization effect of the surfactant. Further increase in the concentration of the surfactant, the intensity of the $421 \mathrm{~nm}$ band stabilized with a corresponding appearance of another absorption maximum at $486 \mathrm{~nm}$. The $486 \mathrm{~nm}$ band can be attributed to the interaction of 5-Me-TAR with DDPC micelles, where the micelles start forming at around $4.0 \times 10^{-4} \mathrm{~mol} \mathrm{dm}^{-3}$. The visible spectra are fixed after a specific surfactant concentration. The variation of $A / A_{o}$ values with the logarithm of surfactant concentration is shown in Fig. 3. The breaking point of the plot is considered the critical micelle concentration of surfactant (Hait et al 2001). Similar changes were observed with the addition of other surfactants, which are tabulated in Table 1.

Since the shift in the absorption spectrum results from the interaction between the dye and the surfactant, the shift in $\lambda_{\max }$ can be used to measure the interaction between molecules. The interaction between cationic surfactant micelles with dye, stronger than those anionic and nonionic ones. It has also been noticed that the shift in the absorption band of the dye is less in DDPC micelles (from 421 to $486 \mathrm{~nm}$ ) compared to that in the CPC micelles (from 421 to $494 \mathrm{~nm}$ ). This illustrates that the interaction between the dye and surfactant depends not only on ionic interactions but also hydrophobic nature of the surfactant used. 
Table 1. Spectral properties of 5-Me-TAR in water and micellar solutions.

\begin{tabular}{|c|l|c|c|c|}
\hline $\begin{array}{c}\text { Aqueous } \\
\text { solution }\end{array}$ & \multicolumn{4}{|c|}{ Micellar solution } \\
\hline \multirow{3}{*}{$\lambda_{\max }(\mathrm{nm})$} & Surfactant & $\begin{array}{c}\lambda_{\max } \\
(\mathrm{nm})\end{array}$ & $\begin{array}{c}\Delta \lambda_{\max } \\
(\mathrm{nm})\end{array}$ & $\begin{array}{c}\text { CMC } \\
(\mathrm{mM})\end{array}$ \\
\hline \multirow{3}{*}{421} & DDPC & 486 & 65 & 17.00 \\
\cline { 2 - 5 } & CPC & 494 & 73 & 0.90 \\
\cline { 2 - 5 } & SDS & 446 & 25 & 8.27 \\
\cline { 2 - 5 } & Triton X100 & 460 & 39 & 0.24 \\
\cline { 2 - 5 } & Tween 20 & 476 & 55 & 5.00 \\
\hline
\end{tabular}

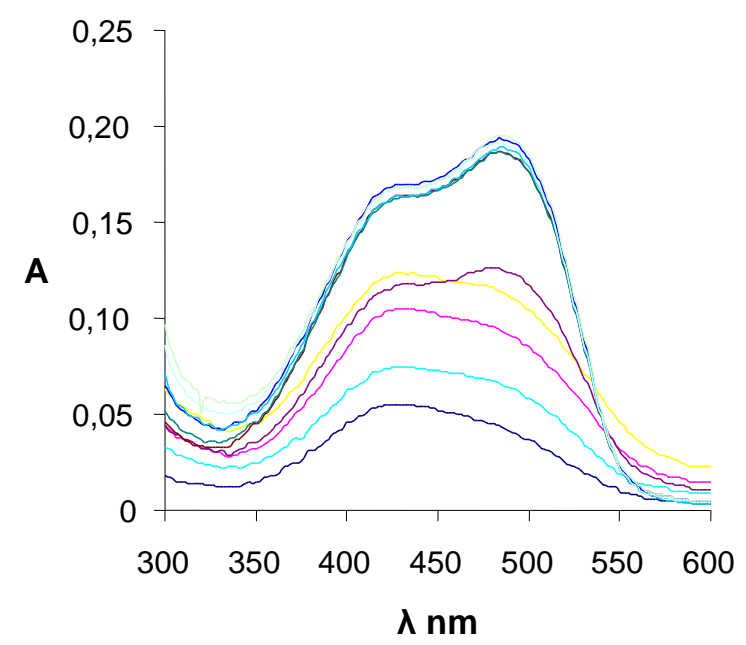

Fig. 2. VIS spectra of $1 \cdot 10^{-5} \mathrm{M} 5-\mathrm{Me}-\mathrm{TAR}$ in the presence of DDPC

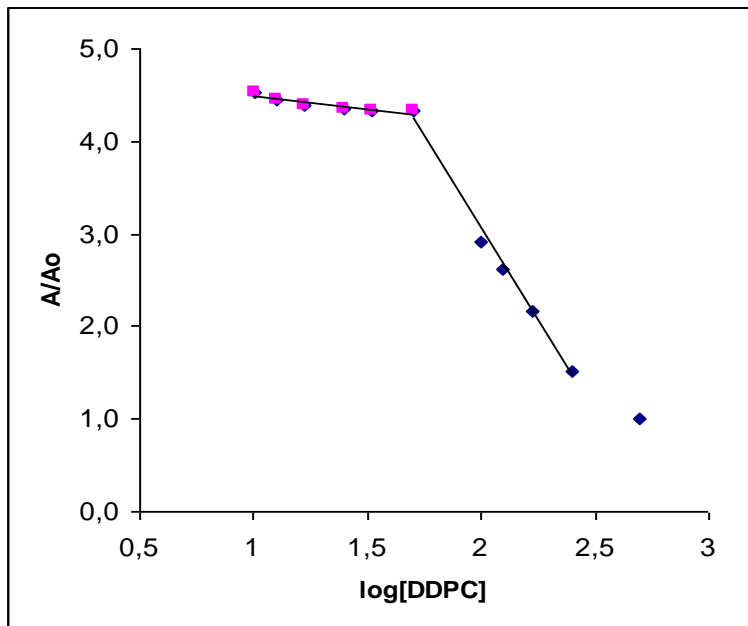

Fig. 3. The variation of $A / A_{o}$ (at $\lambda_{\max }=486 \mathrm{~nm}$ ) with the logarithm of DDPC concentration. 


\subsection{Surfactant Effects on Voltammetric Behaviour of Dye}

Our previous study deals with a detailed electrochemical study of the dye and a reduction mechanism suggested for a broad $\mathrm{pH}$ range $(\mathrm{pH} 2-12)$. The study showed that 5-Me-TAR yields a single wave or peak in the range of $\mathrm{pH}$ 2-10 studied but two peaks were observed at higher than $\mathrm{pH}>10$ with the SWV, DPP, DCP, and CV techniques. The azo dye reduced reversibly to hydrazo form by taking two electrons and two protons at neutral $\mathrm{pH}$ region on the hanging mercury drop electrode (Menek and Topçu, 2003).

The CMC depends on the nature of surfactant (e.g. surfactant type, charge, and alkyl length vs) and solution medium (e.g. temperature, ionic strength vs) (Medel et al. 1986, Charlotte et al 2010). Since the CMC of surfactants has a different value when designating the worked concentrations the $\mathrm{CMC}$ of the surfactants are taken into account. A wide range of concentrations was used in the study, which covers concentrations both below and above CMC. Cyclic voltammograms of the dye were taken at a fixed dye concentration and ionic strength to determine the effects of surfactant type and concentration.

The cyclic voltammograms of the dye alone were shown at different scan rates between 20 to $1000 \mathrm{mV} / \mathrm{s}$ in $0.1 \mathrm{M} \mathrm{KNO}_{3}$ medium at $\mathrm{pH} 7$.

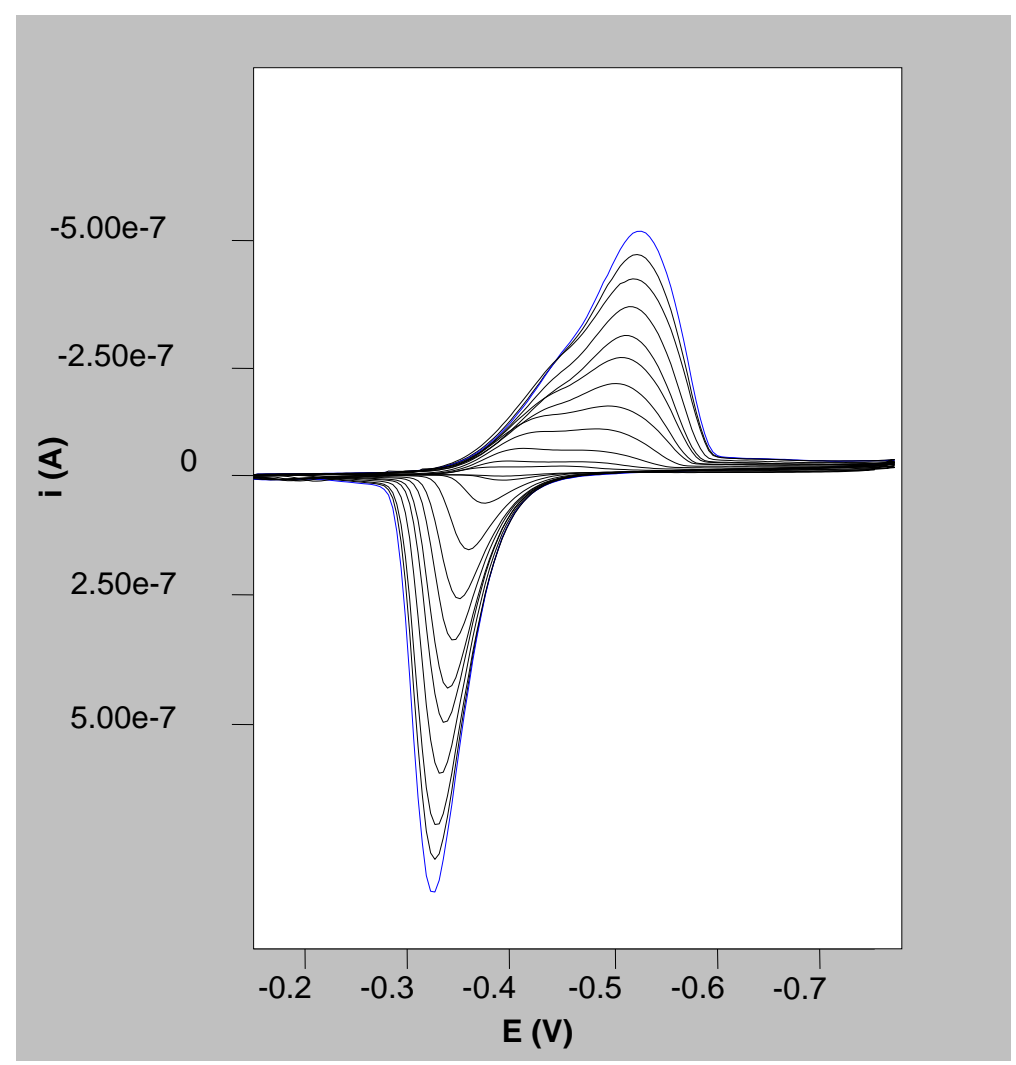




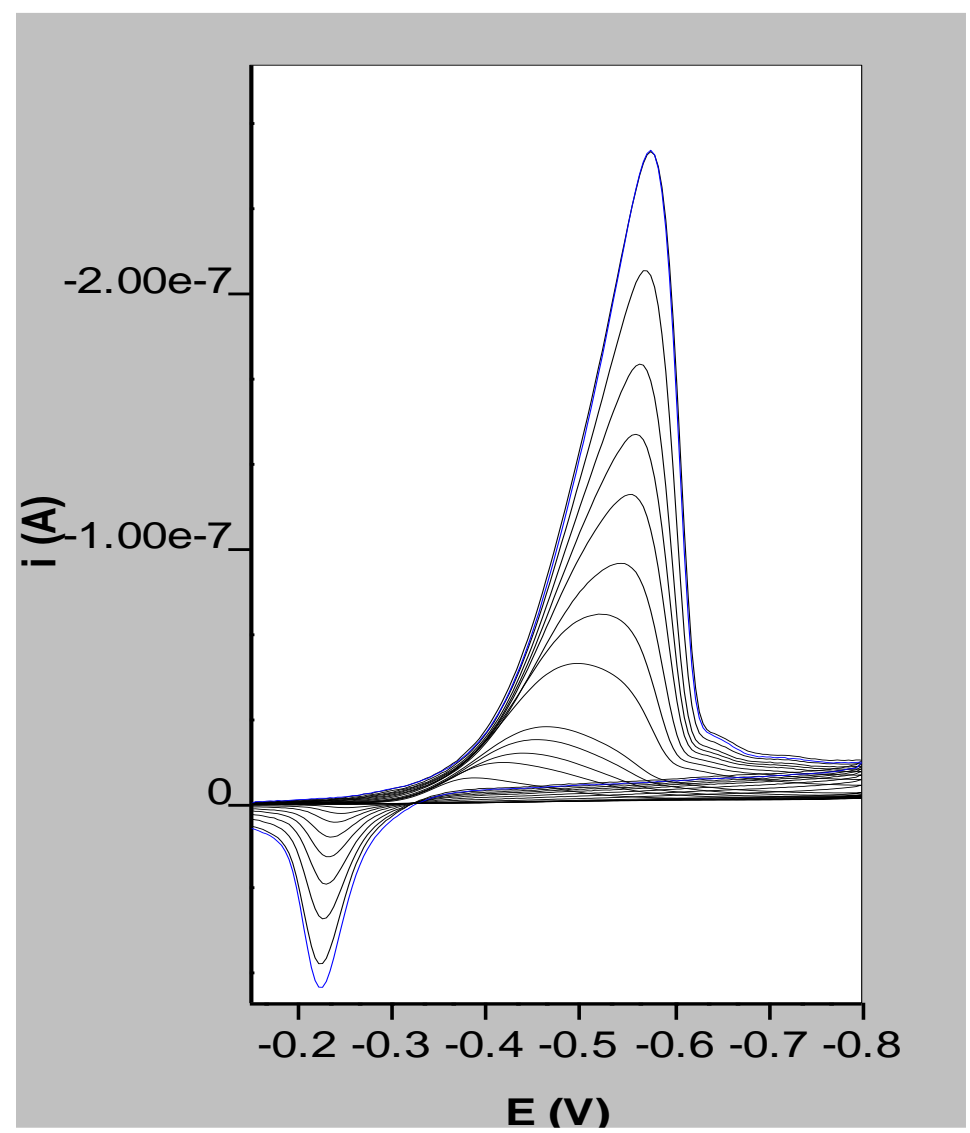

Fig. 4 Cyclic voltammograms of (a) 5-Me-TAR alone $9 \times 10^{-6} \mathrm{M}$ and (b) in the presence of 0.1 $\mathrm{mM}$ CPC (scan rate:20-1000 mV/s).

Voltammograms show that the electrode process involves adsorption complications (Fig. 4a). The presence of adsorption is verified by the difference between anodic-cathodic peak potentials and anodic to cathodic peak ratio, which is greater than 1. Also, the slope of the $\log i_{\mathrm{pc}}-\log v$ graph of the dye was found to be 0.98 and higher than 0.5 . These results indicate that 5-Me-TAR is adsorbed to the electrode surface at this concentration. Moreover, cyclic voltammograms were recorded to make a comparison in the ethanole-water mixture. The peak ratio $\mathrm{i}_{\mathrm{p}}{ }^{\mathrm{a}} / \mathrm{i}_{\mathrm{p}}{ }^{\mathrm{c}}$ of the ethanole-water mixture $(\% 30 \mathrm{v} / \mathrm{v})$ smaller than 1 showed that the absence of adsorption in this medium. The presence of strong intermolecular interaction of dye and ethanol molecules prevents the adsorption of dye as expected.

The presence of a surfactant molecule in the dye solution leads to a similar electrochemical response in ethanole-water media. The stepwise manner addition of surfactant into dye solution leads to a sharp decrease in the anodic peak to cathodic peak current ratio. A representative cyclic voltammogram of cationic CPC solution was shown in Figure 4b. In all surfactant solutions, similar voltammograms were observed. These changes are attributed to the adsorption of the surfactant to the electrode surface and therefore inhibit the adsorption of the dye.

The variation in peak potential and peak current of 5-Me-TAR in surfactant solutions are shown in Figures 5 and 6, respectively. In the presence of SDS and Triton X100, the peak current of the dye slightly increased in the early stage of surfactant addition. Further addition of these surfactants caused a sharp decrease in the peak current. CPC, DDPC, and Tween 20 reduced the peak current as soon as they were added to the solution. 
Electrochemical Behaviour of 5-Methyl-4-(2-Thiazolylazo)-Resorcinol in Micellar Media
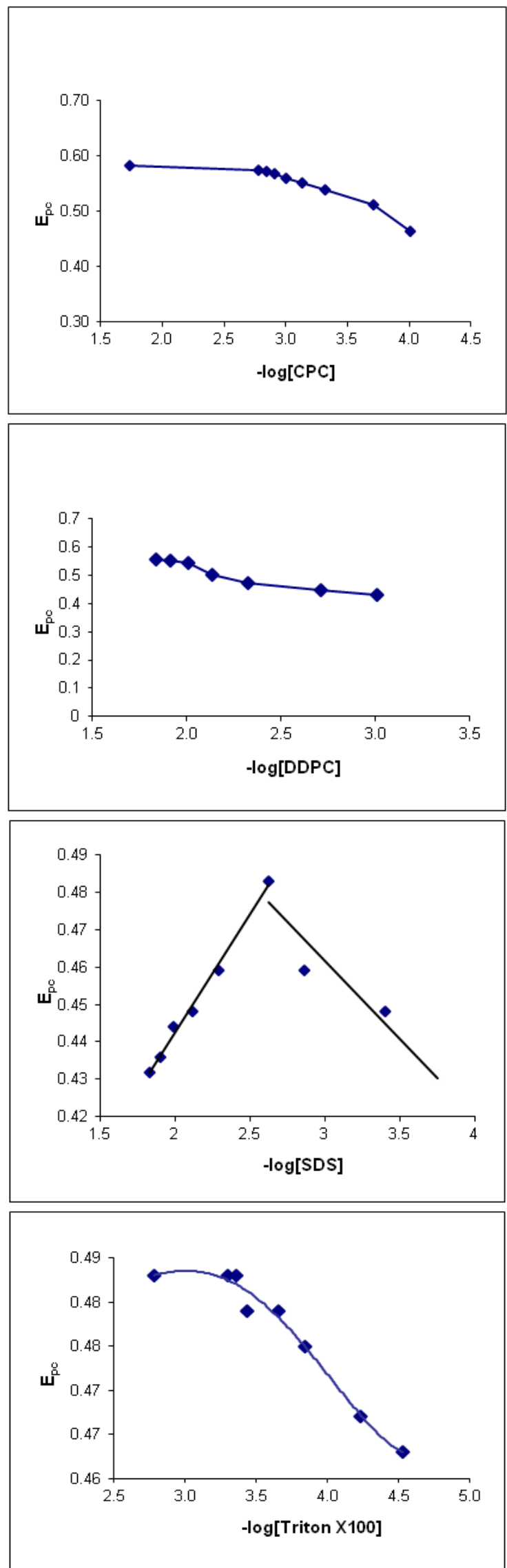
Electrochemical Behaviour of 5-Methyl-4-(2-Thiazolylazo)-Resorcinol in Micellar Media
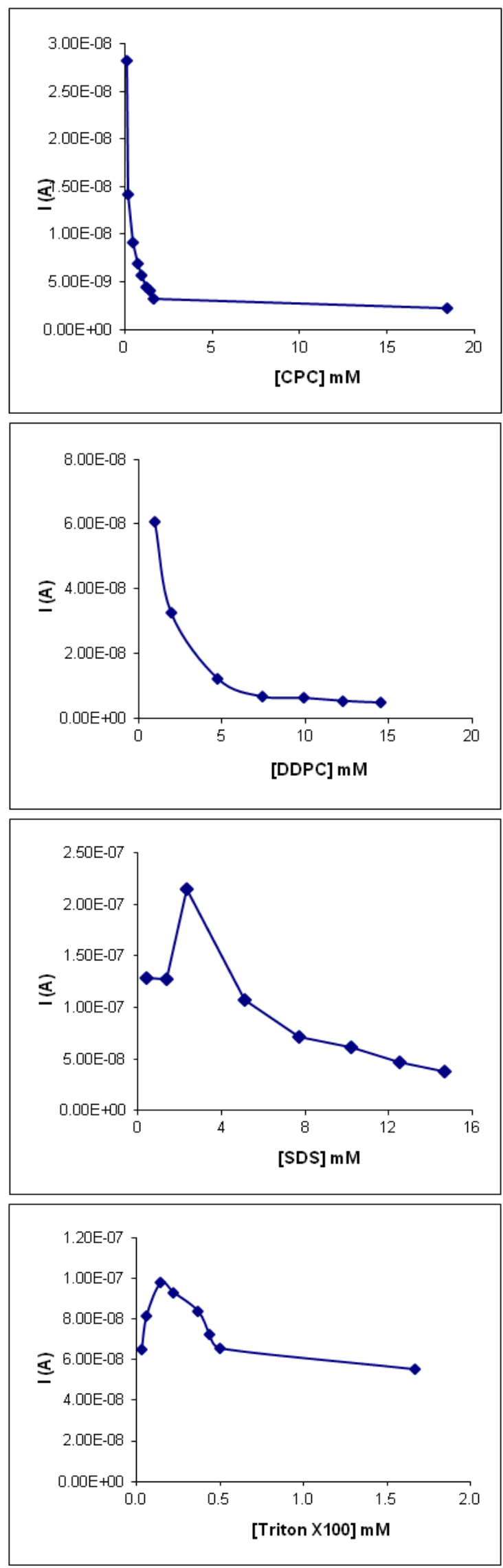


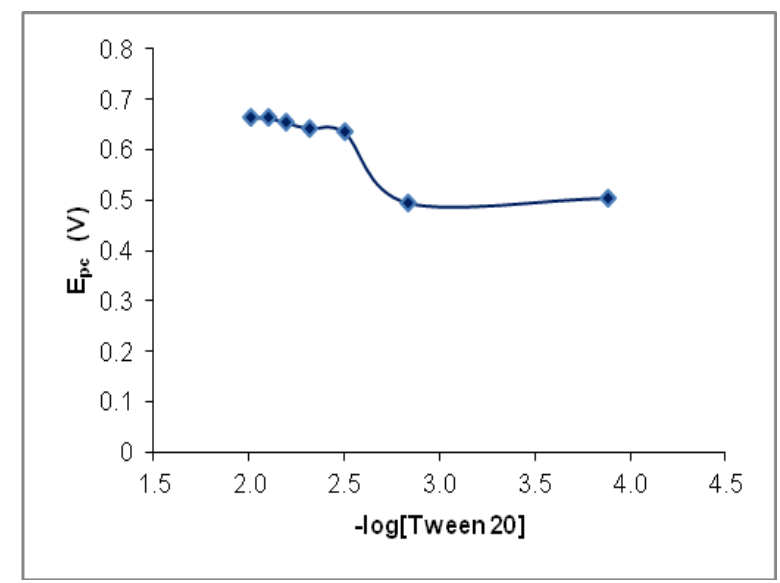

Fig. 5. The peak potential $\left(-\mathrm{E}_{\mathrm{pc}}\right)$ versus the logarithm of surfactant concentration

The negative shift of the peak potential means that reduction of the dye becomes more difficult to occur with increasing surfactant concentration.

Triton X100 addition into the dye solution barely changed the reduction potential $(25 \mathrm{mV})$. It remained in the range of $0.46-0.48 \mathrm{~V}$. The peak current raised until the $\mathrm{CMC}$ of the surfactant $(0.24 \mathrm{mM})$ and then decreased and become constant.

CPC, DDPC, and Tween 20 showed similar behavior in the electrochemical reaction. The peak potentials shifted to more negative values with increasing concentration and then fixed around a certain potential value. CPC and DDPC changed the peak potential from $0.46 \mathrm{~V}$ to $0.58 \mathrm{~V}$ and $0.43 \mathrm{~V}$ to $0.55 \mathrm{~V}$, respectively. Tween 20 leads to a greater shift $(160 \mathrm{mV})$ from $0.50 \mathrm{~V}$ to $0.66 \mathrm{~V}$. Although equal variation $(120 \mathrm{mV})$ is observed both in CPC and DDPC, these changes occurred at much lower concentrations in CPC. The peak current of the dye sharply decreased until the CMC of the used surfactant (Table 1). Then approach to a lower limit value (Fig. 6). Moreover, these three surfactants also caused a larger bathochromic shift in absorption spectra (Table 1).

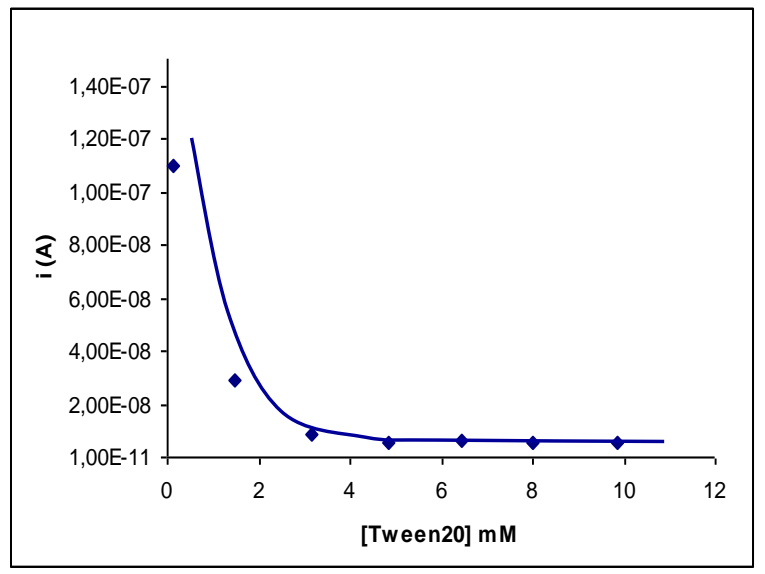

Fig. 6. The peak current $\left(\mathrm{I}_{\mathrm{pc}}\right)$ of 5-Me-TAR in surfactant solutions

SDS and Triton X100 showed an increase in peak currents below their CMC values, suggesting that a surfactant-induced surface process has caused this change. 
The surfactant concentration dependency of the reduction potential in SDS deviated from others. While the anionic surfactant initially increased the reduction potential from $0.43 \mathrm{~V}$ to $0.48 \mathrm{~V}$, then decreased it to $0.44 \mathrm{~V}$ at higher concentrations. The electrode reaction becomes more difficult due to the interaction of SDS, which is strongly adsorbed on the electrode surface, with the anionic form of the dye. Further increase in the bulk concentration of SDS leads to anion-anion interactions that alter the protonation equilibria of the dye and thus convert the anionic dye to its neutral form. Thus, electro-reduction of 5-Me-TAR, which involves protonation of the dye on the electrode surface, occurs more easily (Uçar et al, 2002, Menek et al 2003).

The electrode reaction of 5-Me-TAR is highly sensitive to the presence of surfactants in the dye solution. The variation of peak potential and peak current of the dye with the surfactant concentration showed rapid changes in specific concentration ranges. These changes indicate that surfactant monomers begin to aggregate to form a micellar structure. Evaluation of peak potentials and currents together showed that critical micelle concentrations of surfactants in 5Me-TAR solution can also be found by voltammetry. The critical micelle concentrations were in agreement with those found by the spectroscopic method (Table 1).

The peak current of the dye almost stayed constant after this surfactant concentration. As the surfactant concentration is increased there is a considerable decrease in the slope of the $\mathrm{I}_{\mathrm{pc}} \mathrm{vs}$. $v^{1 / 2}$ plot. This may be due to an increase in effective size and high viscosity of the micellar solutions, which retard the diffusion of the encapsulated dye (Das et al 1997, Davis et al 1998).

\section{Conclusion}

The presence of surfactant in the dye solution significantly changed the electronic absorption spectra and electro-reduction of the dye reaction on the mercury electrode. The increase in the absorption spectrum before the critical micelle concentration indicates that the dye dissolves better in the presence of surfactant. However, it has been found that it effectively prevents the adsorption of the dye to the mercury electrode surface up to the critical micelle concentration and makes the electrode reaction diffusion-controlled. When the critical micelle concentration was exceeded, the formation of a new peak in the absorption spectrum showed that the dye remained within the micelle structure and its immediate surroundings changed from a hydrophilic structure to a hydrophobic structure. The trapping of 5-Me-TAR in micelles significantly reduced the diffusion rate to the electrode. The peak current of the electrochemical reaction gradually decreased in micellar media. These effects were more pronounced with cationic surfactants than others. It shows that cationic surfactants and the dye interact with each other beyond Van der Waals forces. Considering the acidic nature and ionization of 5-Me-TAR in aqueous media, the Coulomb force plays an active role in the interaction between cationic surfactants and dye anions.

This study showed that surfactant-dye interactions could be used to separate overlapping peaks of different dyestuffs in voltammetric determination (Kumar et al 2021). Tween 20 provided the largest peak shift $(160 \mathrm{mV})$, followed by CPC and DDPC with $120 \mathrm{mV}$. SDS caused a change of about $50 \mathrm{mV}$, while the Triton X100 was found to have an effect of only $25 \mathrm{mV}$. A peak shift above around $100 \mathrm{mV}$ can be useful in many overlap situations (Selcuk et al 2021). The use of excess surfactant to achieve good peak separation can become the limiting factor since it reduces the peak currents. 


\section{References}

Allahverdiyeva, S., Pınar, PT., Keskin, E., Yunusoğlu, O., Yardım, Y. Şentürk, Z., 2020. "Adsorptive stripping voltammetric determination of higenamine on a boron-doped diamond electrode improved by the use of an anionic surfactant", Sensors and Actuators B: Chemical, Volume 303, 2020, 127174.

Amin AS, 2000. "The surfactant-sensitized analytical reaction of niobium with some thiazolylazo compounds", Microchemical Journal, 65: 261-267.

Charlotte R.C, Serrano KG, Savall A, 2010. "Voltammetric determination of the critical micellar concentration of surfactants by using a boron doped diamond anode", Journal of Applied Electrochemistry, 40: 1845-1851.

Das DK, Bhattaray C and Medhi OK, 1997. "Electrochemical behaviour of (protoporphyrinato IX)iron(III) encapsulated in aqueous surfactant micelles", Journal of the Chemical Society Dalton Transactions, 24: 4713-4717.

Dash, S. and Senthilkumar, M. 2021. "Expediting research in Dye - Surfactant interaction: An aid to quick access to knowledge on properties of azodye - An approach", Journal of Emerging Technologies and Innovative Research, 8(3), 78-106.

Davis JM, 1998. "Determination of micellar self-diffusion coefficients by micellar electrokinetic chromatography", Analyst, 123: 337-341.

Fraga ICS, Farias PAM, Ohara AK, 2000. "Determination of molybdenum in the presence of 2-(2-benzothiazolylazo)-p-cresol by catalytic-adsorptive stripping voltammetry", Fresenius Journal of Analytical Chemistry, 366: 307-309.

Gavazov K.B., Delchev V.B., Mileva K.T., Stefanova T.S. and Toncheva, 2016. “A 2:2:2 Complex of Vanadium(V) with 4-(2-Thiazolylazo)orcinol and 2,3,5-Triphenyl-2HTetrazolium Chloride", Acta Chimica Slovenica, 63(2).

Genc F, Milcheva NP, Hristov DG, Gavazov KB, 2020. "A simple cloud point extraction-spectrophotometric method for total vanadium determination using 4-(2-thiazolylazo)resorcinol and $\mathrm{H}_{2} \mathrm{O}_{2}$ ", Chemical Papers, 74: 1891-1901.

Gomes Teixeira LSG, Costa ACS, Sérgio Luís Costa Ferreira SLC, Freitas M de L, Carvalho M S. 1999. "Spectrophotometric Determination of Uranium Using 2-(2- Thiazolylazo)-pCresol (TAC) in the Presence of Surfactants", Journal of Brazialian Chemical Society, 10(6): 519-522.

Hait SK and Moulik SP, 2001. "Determination of critical micelle concentration (CMC) of nonionic surfactants by donor-acceptor interaction with iodine and correlation of CMC with hydrophile-lipophile balance and other parameters of the surfactants", Journal of Surfactants and Detergents, 4:(3) 303-309.

Karaman Y and Menek N, 2012. "Investigation of Electrochemical Behavior of 2-(5-Bromo2-Pyridylazo)-5-[N-Propyl-N-(3-Sulfopropyl)Amino]Phenol Disodium Salt Dihydrate," Journal of The Electrochemical Society, 159(10): H805-H810. 
Karaman Y, Menek N, Arslan Bicer F,. Olmez H, 2015. "Voltammetric Investigations of 2,2'-Azobispyridine Zinc(II) and Nickel(II) Complexes", International Journal of Electrochemical Science, 10: 3106-3116.

Karaman Y, 2014. "Investigation of electrochemical behavior of Calmagite at a glassy carbon electrode", Dyes and Pigments, 106: 39-44.

Kumar, M., Fu, Y., Wang, M., Swamy, B.E.K., Jayaprakash, G.K., Zhao, W. 2021. "Influence of cationic surfactant cetyltrimethylammonium bromide for electrochemical detection of guanine, uric acid and dopamine", Journal of Molecular Liquids, (321).

Medel, S.A. and Garcia, M.E.D. 1986. "Dye-Surfactant Interactions: A review",Talanta, 38(3), 255-264.

Menek, N., Eren, E. and Topçu, S. 2006. "Kinetic investigation of an azo dye oxidation by hydrogen peroxide in aqueous surfactant solution”, Dyes and pigments, 68(2-3), 205-210.

Menek, N. and Topçu, S. 2003. "Electrochemical behaviour of 5-methyl-(2-thiazolylazo)resorcinol", Bulletin of Electrochemistry, 19(3), 133-137.

Niazi A, Yazdanipour A, 2008. "Simultaneous spectrophotometric determination of cobalt, copper and nickel using 1-(2-thiazolylazo)-2-naphthol by chemometrics methods", Chinese Chemical Letters, 19: 860-864.

Rahman MM, Mollah MYA, Rahman MM, and Abu Bin Hasan Susan Md, 2013. "Electrochemical Behavior of Malachite Green in Aqueous Solutions of Ionic Surfactants", ISRN Electrochemistry, 3: 1-10.

Rajeev Jain, Anzarul Haque, Alka Verma 2017. "Voltammetric quantification of surfactant stabilized curcumin at MWCNT/GCE sensor", Journal of Molecular Liquids, 230, 600-607.

Selcuk, O., Erkmen, C., Bozal-Palabiyik, B. and Uslu, B., 2021. "Electroanalytical Investigation and Simultaneous Determination of Etodolac and Thiocolchicoside at a Nonmodified Glassy Carbon Electrode in Anionic Surfactant Media”, 33(5), 1290-1298.

Sener, C.E., Dogan Topal, B. \& Ozkan, S.A., 2020. "Effect of monomer structure of anionic surfactant on voltammetric signals of an anticancer drug: rapid, simple, and sensitive electroanalysis of nilotinib in biological samples". Anal Bioanal Chem 412, 8073-8081 (2020).

Smolinska M, Korkuna O, Vrublevska T, Rudchuk P, Teslyar G, 2015. "Development and validation of the simple and sensitive spectrophotometric method of sulphanilamides determination with 4-(2-thiazolylazo)-resorcinol in veterinary preparations", Open Chemistry, 13: $1254-1268$.

Toncheva, G.K., Milcheva,N.P. and Gavazov, K.B. 2018. "Liquid-Liquid ExtractionChromogenic System for Vanadium(V) Based on 4-(2-thiazolylazo)orcinol (TAO) and Aliquat", Acta Chimica Slovenica, 65(4), 336.

Topçu, S and Menek, N. "IV. Elektrokimya Günleri Bildiri Kitabı", bildiri kitapçı̆̆ındaki "Ni2-(5-Bromo-2- Piridilazo)-5-Dietilamino-Fenol Kompleksi Üzerine Yüzey Aktif Madde Etkisinin Polarografik ve Voltametrik İncelenmesi", 224-227, Adana, Türkiye, Haziran, 2003 
Uçar M,. Solak AO, Menek N, 2002. "Electrochemical Behavior of 2'-Halogenated Derivatives of $N, N$-Dimethyl-4-aminoazobenzene at Mercury Electrode", Analytical Science, 18: 997-1002.

Uçarlı O, 2020. "Voltammetric Determination of Catalytic Effect of Nitrite in Nitrate Media by Graphite and Mercury Electrode on Acid Red-27 Cobalt Complex", Erzincan Üniversitesi Fen Bilimleri Dergisi, 13(3), 1289-1298.

Wang H, Zhang H-S, Cheng J-K, 1999. "Studies on 2-(2-thiazolylazo)-5-diethylaminophenol as a precolumn derivatizing reagent in the separation of platinum group metals by high performance liquid chromatography", Talanta, 48: 1-7.

Wu JJ, Wen-ting W.W., Wang M, Hong L.H and Hong-chun P.H., 2016. "Electrochemical Behavior and Direct Quantitative Determination of Tanshinone IIA in Micro-emulsion", International Journal of Electrochemical Science, 11: 5165-5179. 